\title{
Phenology and mortality of embryos in a Colombian population of Nymphargus grandisonae (Anura: Centrolenidae)
}

\author{
Daniela Villegas-Mora, ${ }^{1}$ Sebastian Muñoz-Acevedo, ${ }^{1}$ Estefany Caroline Guevara-Molina, ${ }^{2}$ and \\ Fernando Vargas-Salinas ${ }^{1}$ \\ ${ }^{1}$ Facultad de Ciencias Básicas y Tecnologías, Programa de Biología, Universidad del Quindío. 630008, Armenia, Quindío, \\ Colombia. \\ ${ }^{2}$ Laboratório de Comportamento e Fisiologia Evolutiva, Departamento de Fisiologia, Instituto de Biociências, Universidade de \\ São Paulo. 05508-040, São Paulo, SP, Brazil. E-mail: scarolinemolina@usp.br.
}

\begin{abstract}
Phenology and mortality of embryos in a Colombian population of Nymphargus grandisonae (Anura: Centrolenidae). Studies of phenology and natural history of anurans provide information useful for its conservation. This is particularly important in current scenarios of emergent diseases, high rates of deforestation, and climate change. We recorded the timing of breeding of the Glass Frog Nymphargus grandisonae and its relationship to precipitation and environmental temperature for four years in a population located in the Central Andes of Colombia, South America. In addition, we recorded the causes of mortality in egg clutches of this species. We quantified infestation by fly larvae and its impact on the survival of embryos. We found that the reproductive activity of $N$. grandisonae (number of males calling) was seasonal and occurred in months with highest precipitation. The main cause of embryo mortality in clutches was associated with the infestation by a spittlebug fly of the genus c.f. Cladochaeta (Drosophilidae). The survival of embryos in infested clutches was significantly lower than in those clutches not infested by fly larvae. Our results provide baseline data for the monitoring of anuran population dynamics in the Andean region using the glass frog $N$. grandisonae as a model system.
\end{abstract}

Keywords: Amphibians, Glass Frogs, fly larvae infestation, timing of breeding.

\begin{abstract}
Resumo
Fenologia e mortalidade de embriões em uma população colombiana de Nymphargus grandisonae (Anura: Centrolenidae). Estudos de fenologia e história natural dos anuros fornecem informações úteis para sua conservação. Isso é particularmente importante nos cenários atuais de doenças emergentes, altas taxas de desmatamento e mudanças climáticas. Monitoramos a época de reprodução da perereca-de-vidro Nymphargus grandisonae (Centrolenidae) e sua relação com a precipitação e a temperatura ambiental durante quatro anos em uma população localizada nos Andes Centrais da Colômbia, América do Sul. Além disso, registramos as causas de mortalidade nas
\end{abstract}

Received 31 July 2020

Accepted 18 November 2020

Distributed December 2020 


\begin{abstract}
desovas dessa espécie. Quantificamos a infestação por larvas de moscas e seus efeitos na sobrevivência dos embriões. Descobrimos que a atividade reprodutiva de $N$. grandisonae (número de machos vocalizando) foi sazonal e ocorreu nos meses de maior precipitação. A principal causa de mortalidade embrionária nas desovas esteve associada à infestação por uma mosca do gênero c.f. Cladochaeta (Drosophilidae). A sobrevivência de embriões em desovas infestadas foi significativamente menor do que naquelas não infestadas pelas larvas da mosca. Nossos achados fornecem dados básicos para o monitoramento da dinâmica populacional de anuros na região Andina usando a perereca-de-vidro $N$. grandisonae como modelo de estudo.
\end{abstract}

Palavras chave: anfíbios, época de reprodução, infestação por larvas de mosca, pererecas-de-vidro.

\section{Introduction}

Phenology or the timing of breeding of organisms is influenced by biotic and abiotic factors of the environment (van Shaik et al. 1993, Mistlberger and Rusak 2005, Chuine and Régnière 2017). Precipitation, temperature, and photoperiod seem to be the most important abiotic factors affecting timing of breeding in diverse vertebrates. Those factors influence patterns of photosynthesis, growth, and reproduction in plants, which in turn determine the availability of food items that trigger breeding activity in vertebrates (Losos 2009, Lillywhite 2014, Winkler 2016, Strier 2017). On the other hand, biotic factors influencing timing of breeding include predation and competition. For instance, nest predation and interspecific competition might delay reproduction and determine the use of specific places for breeding in birds and mammals (Verhulst and Tinbergen 1991, Samplonius and Both 2017, Strier 2017). Timing of breeding is often less constrained in tropical humid regions than in highly seasonal environments such as those in temperate regions and arid regions (Winkler 2016, Strier 2017, Torres-Cervantes et al. 2019). Moreover, timing of breeding can be plastic in many organisms, but such plasticity is constrained by developmental, hormonal, genetic and evolutionary aspects (Sockman et al. 2006, Chuine and Régnière 2017).

Amphibian anurans are ectothermic vertebrates with complex life cycles that depend directly on environmental conditions for survival and reproduction (Duellman and Trueb 1994, Wells 2007). Given that anurans are present in almost all areas of the world, species in this clade face diverse environmental conditions, likely leading to high variation in timing of breeding that reflects adaptations to local conditions (Andrade et al. 2016, HernándezSalinas et al. 2018, Torres-Cervantes et al. 2019, Vargas-Salinas et al. 2019). In both temperate and tropical regions, anurans exhibit explosive and prolonged breeding; the former are those species whose breeding events endure only one or few nights, while the latter are those species whose breeding persist several weeks (Wells 1977). Whether an anuran species is a prolonged or explosive breeder is attributed in part to abiotic factors of the environment, especially precipitation and temperature. These factors determine the availability of food that a species can invest in breeding and the availability of resources used directly for breeding (McCauley et al. 2000, Wells 2007). Timing of breeding in anurans aids in understanding the outcome of biotic interactions and also provides information for detecting and monitoring potential effects of disturbances and environmental changes (Paton and Crouch III 2002, Lips et al. 2005, Llusia et al. 2013, Walls et al. 2013).

In the Andes of northern South America, hundreds of anuran species have a restricted distribution (Navas 2006, Bernal and Lynch 2008, Vasconcelos et al. 2019). Among those species, glass frogs (Centrolenidae) comprise a 
clade with more than 155 species that have reached their highest species diversity at intermediate altitudes (Hutter et al. 2013a, Frost 2020) where the effects of emergent diseases, deforestation and climate change are expected to be particularly strong (Lips et al. 2005, Navas 2002, 2006, Navas et al. 2013). Glass frog females deposit their eggs on substrates out of water along streams, and after several days or weeks (e.g. > 20 days), the eggs hatch and embryos fall into the water where they complete development (Cisneros-Heredia and McDiarmid 2007). Because of their oviposition out of water, it is generally assumed that the timing of breeding in glass frogs is associated with seasons of high rainfall; however, some species reproduce during the summer season (Delia et al. 2010, Cabanzo-Olarte et al. 2013, Ortiz-Ross et al. 2020). In addition, timing of breeding can change between populations or even within a single population among years depending on variations in environmental factors (Wells 2007, Dodd et al. 2012). This variability in timing of breeding restricts generalizations found in studies of specific taxa and highlights the necessity to quantify phenology in a diversity of species (Duellman and Trueb 1994, Wells 2007, OrtizRoss et al. 2020).

In addition to phenology, causes and extent of mortality in anurans provide a quantitative basis for possible alterations in the dynamics of anuran populations (Dodd Jr. et al. 2012). Anurans are subjected to multiple causes and levels of mortality, which is particularly high in egg clutches and larval stages (Wells 2007, Vitt and Caldwell 2014). Glass frog embryos and other lineages of anurans with oviposition out of water are especially susceptible to desiccation (Juncá 1996, Touchon and Warkentin 2010, Delia et al. 2013, 2014, 2019, Salica et al. 2017), predation and parasitism by terrestrial vertebrates and invertebrates (Villa 1977, Villa and Townsend 1983, Hayes 1983a, Warkentin 1995, Neckel-Oliveira and Wachlevski 2004). In some species, mortality can be especially high in early developmental stages when egg capsules are not well hydrated or the embryos have not developed enough to escape predators (Warkentin 1995, Delia et al. 2017, 2020). Predation and infestation by fly larvae are frequently recorded on egg clutches of glass frogs (McDiarmid 1978, Toledo 2007), but their effect on the survival of embryos has rarely been quantified in detail (Villa 1977, Hawley 2006, Delia et al. 2013, Salgado and Guayasamín 2018).

We studied the phenology of the glass frog Nymphargus grandisonae (Cochran and Goin, 1970) and the causes and extent of mortality in its egg clutches. We examined the following two questions: (1) Is the timing of breeding of the glass frog $N$. grandisonae related to levels of precipitation and temperature? and (2) Are embryos in clutches infested by fly larvae more prone to mortality than embryos in uninfested clutches? Our results complement available information for reproductive ecology of glass frogs in the Central Andes of Colombia (e.g. Basto-Riascos et al. 2017, Arcila-Pérez et al. 2017, Ospina-L et al. 2017, Rios-Soto et al. 2017) and provide baseline data for further monitoring of the population dynamics of anurans in the Andean region of northern South America.

\section{Materials and Methods}

\section{Species and Study Area}

Nymphargus grandisonae is a nocturnal and arboreal species distributed in Colombia and Ecuador between 1230-3230 m elevation (Frost 2020, Figure 1). Adult males exhibit a body size (snout-vent length, SVL) between 25.1-29.3 $\mathrm{mm}$, while adult females are a bit larger (SVL: 28.9-30.7 mm) (Duellman 1980, Vanegas-Guerrero et al. 2014). Males are territorial and call from leaves located between 0.5 and $>4 \mathrm{~m}$ height (Hutter et al. 2013b). The clutches have between 30-74 eggs enclosed in a jelly rich matrix, and they are attended by the females for a few hours immediately after oviposition (Ospina-Sarria et al. 2011, Guevara- 
Molina and Vargas-Salinas 2014, Delia et al. 2017, 2020).

This study was performed at the Granja Experimental Bengala $\left(04^{\circ} 41^{\prime} 08.8^{\prime \prime} \mathrm{N}, 75^{\circ} 37^{\prime} 02.9^{\prime \prime} \mathrm{W}\right)$, located in the municipality of Filandia, Quindío department, Central Andes of Colombia (Figure 1 ). The original native vegetation in the area is premontane forest; however, at present the landscape is dominated by open areas used for raising cattle and agriculture (Renjifo 2001). The annual temperature in the study area varies between $12^{\circ} \mathrm{C}$ and $27^{\circ} \mathrm{C}$. The precipitation regime is bimodal, and the average annual rainfall is around $2739 \mathrm{~mm}$. Most rainfall occurs between April-May and October-November (Franco and Bravo 2005, Arcila et al. 2011).

\section{Methodology}

Phenology.-From April 2015 to January 2016 and September 2017 to May 2018, we made 47 fieldtrips, each lasting one or two nights and separated by one or two weeks. Field trips were most frequent in months with higher levels of rainfall because breeding activity of $N$. grandisonae is lower at summer; that is, from January to March and June to August (F. VargasSalinas and C. Guevara-Molina, pers. observ.). Visual encounter surveys (Crump and Scott Jr. 1994) were conducted in two linear transects. One transect (200 m long) was established along a stream, and the other transect (400 m long) was established along a path (Figure 1). The sampled stream and path form an "X"; the path crosses the stream and is directed in a semiparallel way to it in both directions. The longest distance between the stream and a given point on the sampled path was around $20 \mathrm{~m}$. We performed nightly surveys (19:00-00:00 h) to record number of calling males and number of females arriving to breed; diurnal surveys (8:0011:00 h, 14:00-16:00 h) were performed to look for egg clutches and to monitor survival of embryos. Each nocturnal and diurnal survey consisted of walking the two transects by $2-4$ researchers. The total nightly sampling effort in this study was 860 person-hours (April 2015January 2016: 325 h; September 2017-May 2018: $535 \mathrm{~h}$ ), while the total diurnal sampling effort was 830 person-hours (April 2015-January 2016: 325 h; September 2017-May 2018: 505 h).

When a frog or an egg clutch was observed for the first time, we recorded the date, time, and type and height of the substrate. The location was marked with a small labeled flag. Body size of frogs (SVL: snout-vent length to the nearest $\pm 0.01 \mathrm{~mm}$ ) was measured with a digital caliper; the sex was assigned based on calling behavior, body size, presence of humeral spine (in males) and presence of eggs in the belly (females). Photographs of frogs were used as a non-invasive identification technique because individuals of $N$. grandisonae have distinctive red dots on their back that vary in number, size and distribution. The use of color patterns of individuals is useful for unambiguously distinguishing individuals in many anurans (Donnelly et al. 1994, Ferner 2010), and have been successfully used in other studies with glass frogs (e.g. Basto-Riascos et al. 2017, Ospina-L. et al. 2017, Díaz-Ricaurte et al. 2019).

Causes and levels of embryo mortality.A photograph of the clutches was taken during each diurnal and nocturnal survey for recording and monitoring the number of embryos and their stage of development (sensu Gosner 1960, Salazar-Nicholls and del Pino 2015). Because some clutches exhibit infestation by fly larvae (Rojas-Morales and Escobar-Lasso 2013), photographs were also used to document their presence, development and number. For two infested clutches, we placed a small container under the clutch so that the hatched tadpoles fell into it (Hayes 1983b). Those tadpoles were collected and fixed in $96 \%$ alcohol. Three clutches infested by fly larvae were covered with an awning to collect metamorphosed flies. These flies were killed and preserved by 


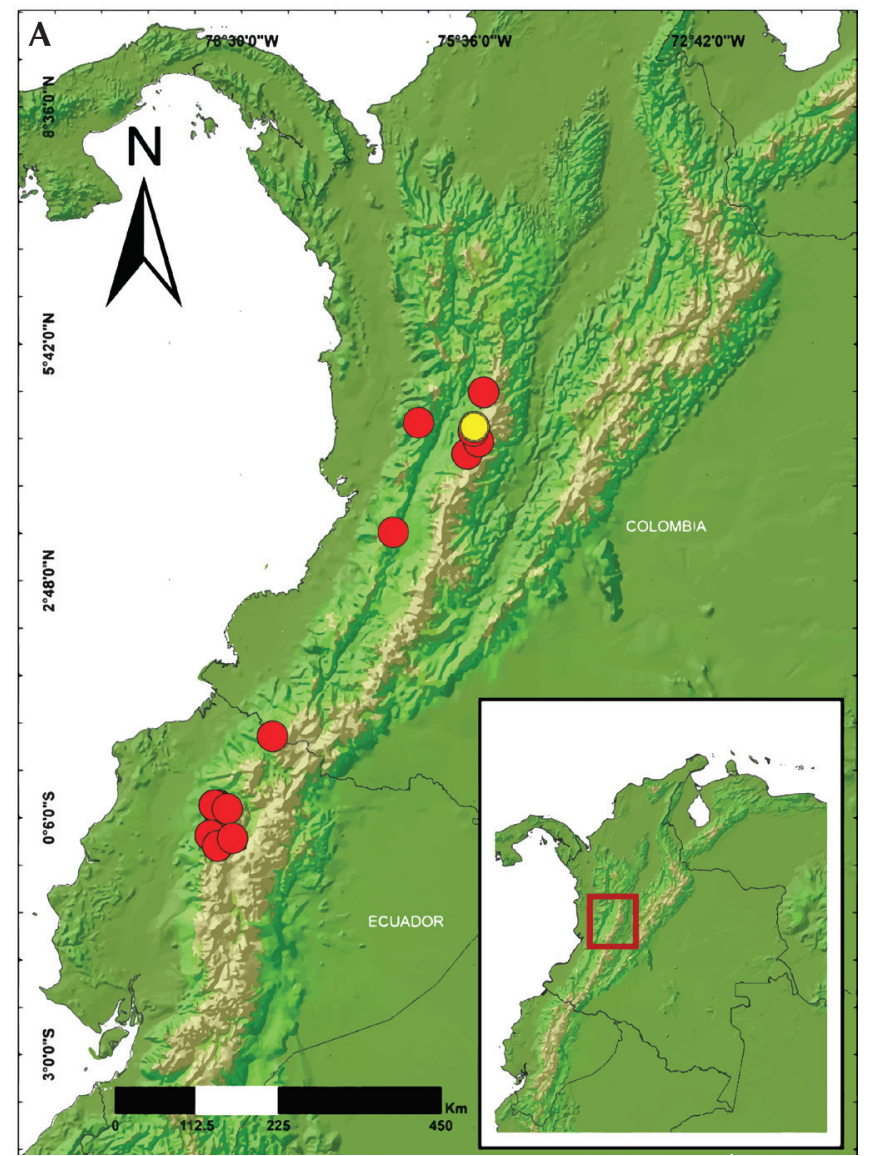

Figure 1. (A) Geographical distribution of the glass frog Nymphargus grandisonae (red dots) highlighting the location of the study area (yellow dot); records based on Yánez-Muñoz (2008), Hutter et al. (2013b), Duellman (1980), Castaño and Carranza-Quiceno (2015) and Arteaga et al. (2013). (B-C) Image of the study area (Granja Experimental Bengala, municipality of Filandia, Quindío, Colombia). In summer, the sampled path is dry, however, during the rainy season, small temporary ponds and streamflow appear.
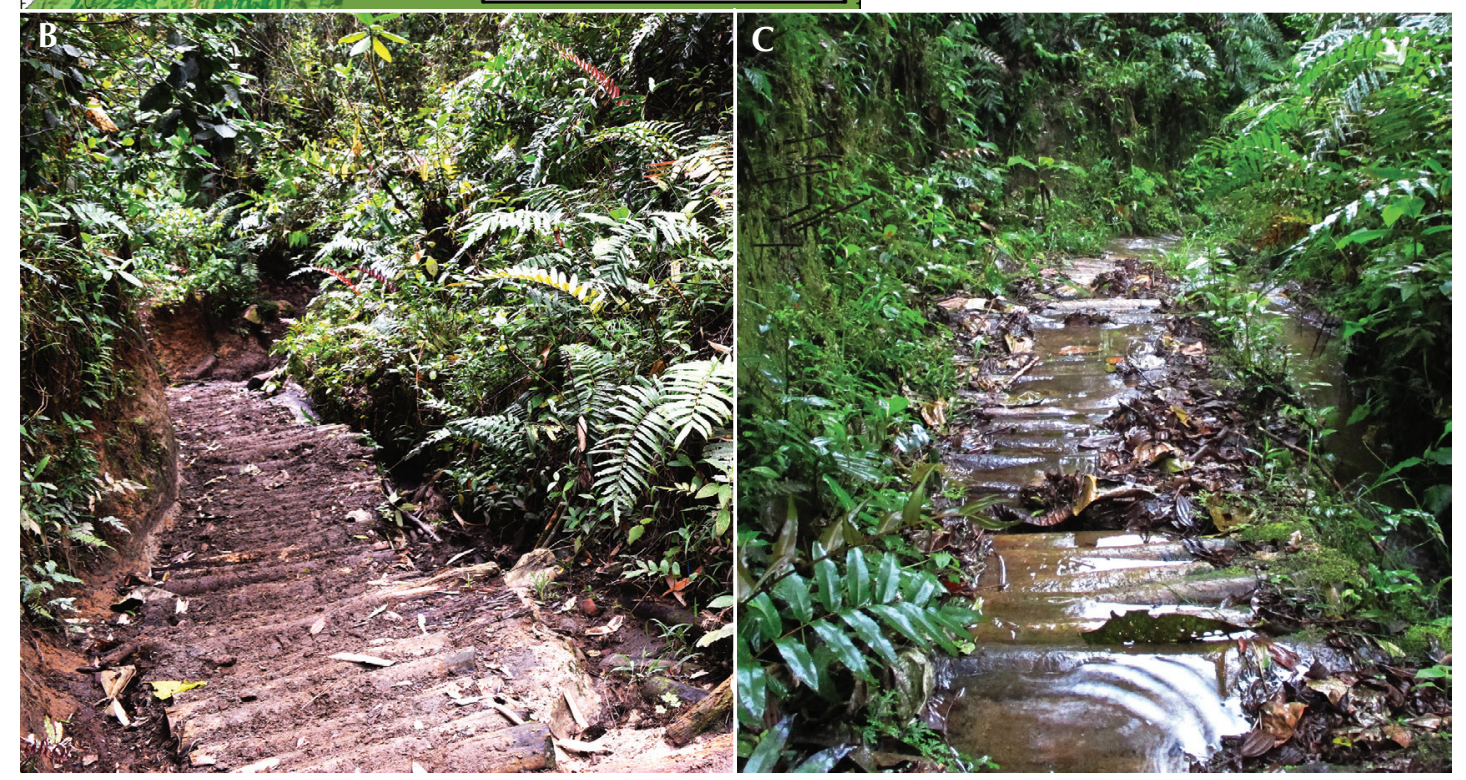
immersion in $96 \%$ alcohol, and identified based on Grimaldi (1990), and with the help of Deivys M. Alvarez (Ph.D student at University of São Paulo, Brazil).

\section{Data Analysis}

Descriptive statistics summarizing the key characteristics of clutches and frogs were recorded in this study and expressed in terms of mean \pm standard deviation (SD) and range in parentheses. To test whether larger males were more prone to call more nights than smaller males we used a Spearman correlation (Sr) analysis. To assess the relationship between environmental factors and breeding activity we used four Spearman correlations, two for testing the relationship of temperature with number of males calling and number of clutches laid by females; the other two for testing the relationship between precipitation level with males calling and number of clutches. For these correlations we pooled data of surveys per month; that is, the unit of analysis was the sampled month $(N$ $=19$ ). As independent variables we used the average value of environmental temperature recorded in a given month; for precipitation level we used total rainfall per month. These environmental data were obtained from a weather station located in the study area (data courtesy of the Corporación Autónoma Regional del Quindío, CRQ). As dependent variables we used the average number of calling males recorded in surveys per month, and the number of egg clutches recorded by the first time per month. To examine the effect of fly larvae infestation on the mortality of embryos of $N$. grandisonae, we performed a KaplanMeier survival test, applying censorship to those clutches whose cause of mortality occurred for other reasons than fly larvae infestation (Therneau and Grambsch 2000). All the mentioned statistical analyses were made with the software program SPSS v.21 (IBM 2012).

\section{Results}

\section{Phenology}

We recorded 31 adult males with an average body size of $28.17 \mathrm{~mm} \pm 2.43$ (22.09-32.31 $\mathrm{mm})$. Most of males called for a small number of nights (1-3 nights, Figure 2). The body size of males was unrelated to the number of nights they called, although a tendency is apparent $(\mathrm{Sr}=$ 0.307, $p=0.093, N=31$ adult males). The mean time elapsed between the first capture and the last recapture of the same male was 130.57 days \pm 102.23 (7-284 days, $N=19$ males). More calling males were found during months with higher precipitation, compared to months with lower precipitation $(\mathrm{Sr}=0.444, p=0.057, N=$ 19 months, Figure 3). Temperature was not related to the number of calling males $(\mathrm{Sr}=$ $-0.191, p=0.433, N=19$ months). A relationship between number of females in breeding activity (i.e. in amplexus or gravid females) and environmental variables was not possible because of the small number of females recorded in our study: eight adult females with an average body size of $32.14 \mathrm{~mm} \pm 1.94$ (29.39-34.32 $\mathrm{mm})$.

We recorded 21 egg clutches on the upper surface of small leaves at $2.02 \mathrm{~m}$ height \pm 0.57 $(0.47-5.00 \mathrm{~m})$. The clutches when first observed consisted of 52.26 eggs \pm 12.52 (17-75 eggs). The number of clutches recorded for the first time was unrelated to precipitation levels $(\mathrm{Sr}=$ $0.319, p=0.183, N=19$ months) and temperature ( $\mathrm{Sr}=-0.209, p=0.390, N=19$ months). In these two analyses we assumed that females laid only one clutch per reproductive season.

\section{Causes and Levels of Embryo Mortality}

Thirteen clutches $(62 \%$ of total clutches located) were infested by spittlebug flies of genus c.f. Cladochaeta: Drosophilidae. These 13 infested clutches exhibited a lower embryo survival than the 8 non-infested clutches 


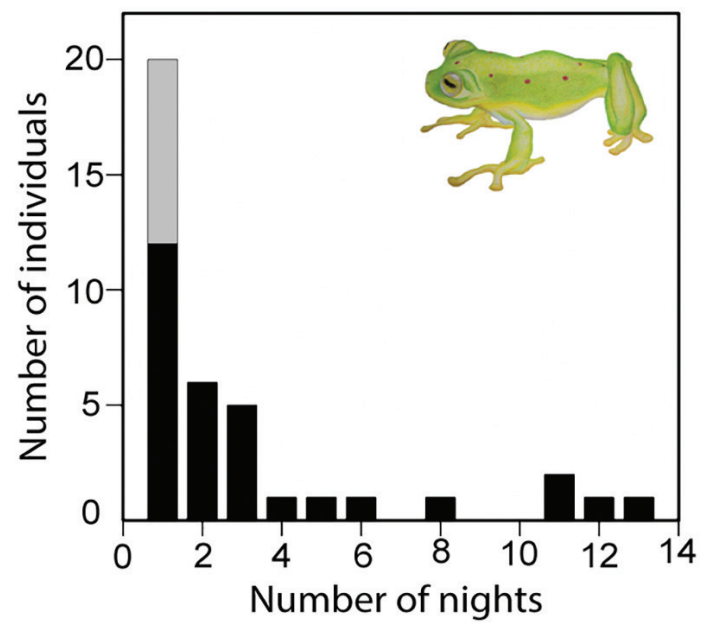

Figure 2. Frequency of breeding activity (number of nights the same frog was recorded) in Nymphargus grandisonae at the Estación Experimental Bengala, department of Quindío, Central Andes of Colombia. The black bars correspond to calling males and the gray bar to females. Illustration of the frog by María José Tovar-Gil.

(Kaplan-Meier Test, $\chi^{2}=5.08, p=0.024$, Figure 4). In one of the two infested clutches in which we implemented the methodology suggested by Hayes (1983b) to catch hatchlings, we recorded 18 embryos of $N$. grandisonae. Those embryos were at development stage 17-18 (sensu Gosner 1960, Salazar-Nicholls and del Pino 2015); the fly larvae in this clutch continued their development normally. The container in the second clutch was lost after heavy rainfall. Another cause of mortality in clutches of $N$. grandisonae was observed. Two egg clutches disappeared after heavy rains; one had 28 fly larvae and no embryos of $N$. grandisonae, and the other had 7 fly larvae and 44 embryos of $N$. grandisonae (development stage 19). During our monitoring we did not observe any predation events on the clutches.

After oviposition, a clutch was composed of a single layer of eggs (Figure 5A) and covered
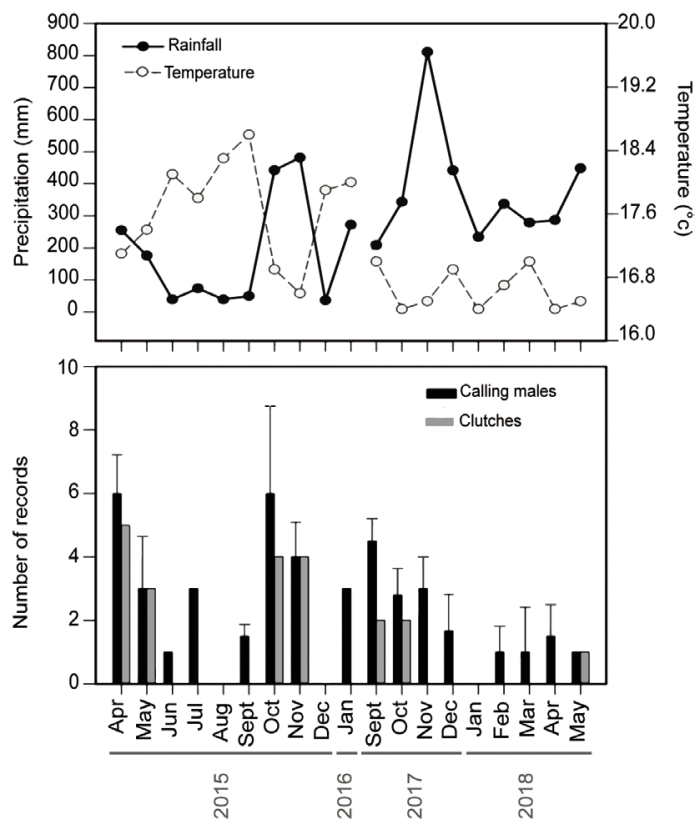

Figure 3. Relationship between precipitation, environmental temperature, and indicators of breeding activity (number of males calling, number of clutches) in the glass frog $\mathrm{N}$. grandisonae. Black bars in the lower plot correspond to averages and standard deviations; Gray bars are the sum of egg clutches observed for the first time each month. We did not perform fieldtrips between February 2016 and September 2017.

by a jelly that began to absorb water from the environment and gain volume (Figure 5B). The first observation of fly larvae infestation was recorded when the embryos were in developmental stage 17-18 (Gosner 1960, Salazar-Nicholls and del Pino 2015). The infestation by fly larvae was evident by the presence of small whitish larvae that spread throughout the jelly covering the eggs (Figure 5C). After some days (5-10), fly larvae grouped in the lower part of the jelly (Figure 5D) where they continued their development until the pupa stage (Figure 5E). Finally, the flies emerged (Figure 5F). 


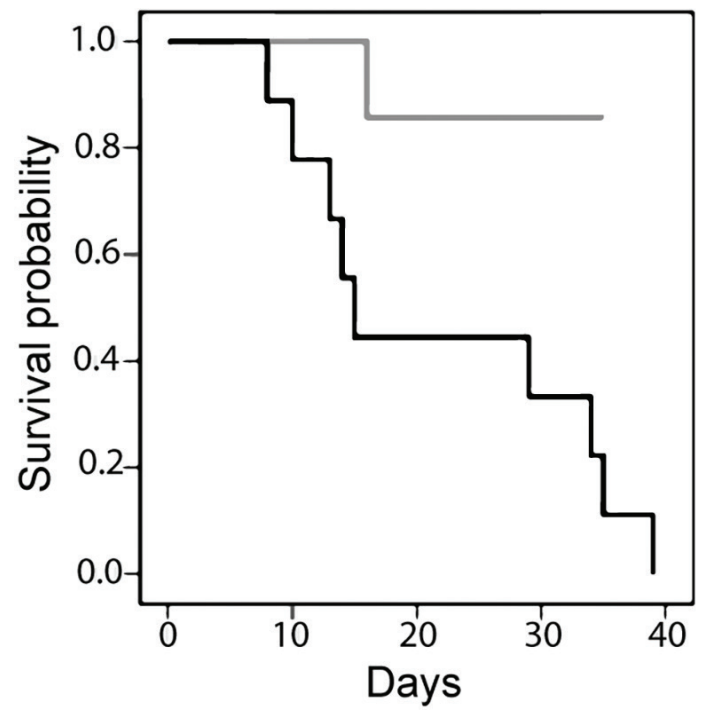

Figure 4. Difference in survival of embryos between infested (black line) and non-infested (grey line) egg clutches of the glass frog Nymphargus grandisonae. Infestation of egg clutches by fly larvae of the genus c.f. Cladochaeta (Drosophilidae). The X-axis corresponds to the number of days passed from the first observation of the clutch (i.e. it does not necessarily reflect time from oviposition).

\section{Discussion}

The timing of breeding of $N$. grandisonae in the study area occurred during months of higher precipitation level. Calling males and the presence of egg clutches were scattered through such months, although with some peaks of male activity at times of highest rainfall. Overall, data suggest that $N$. grandisonae is a seasonal prolonged breeder. Sporadic surveys before and after our sampling periods and the observation of egg clutches throughout the rainy season support this tendency.

Most of the males of $N$. gradisonae called for only few nights (i.e. 1-3 nights). A similar pattern in calling activity of males has been observed in other glass frogs [Hyalinobatrachium fleischmanni (Boettger, 1893) (Greer and Wells
1980); Hyalinobatrachium valerioi (Dunn, 1931) (Mangold et al. 2015); Espadarana prosoblepon (Boettger, 1892) (Basto-Riascos et al. 2017); Centrolene savagei (Ruiz-Carranza and Lynch, 1991) (Ospina-L. et al. 2017)] and other anuran families [Hyperoliidae: Hyperolius marmoratus Rapp, 1842 (Dyson et al. 1998); Dendrobatidae: Oophaga pumilio (Schmidt, 1857) (Pröhl 2003); Hylidae: Hyla arborea (Linnaeus, 1758) (Friedl and Klump 2005); Leptodactylidae: Leptodactylus labyrinthicus (Spix, 1824) (Zina and Haddad 2005)]. This pattern may be the result of trade-offs between costs and benefits of calling (Schaffer 1974, Crenshaw 1966, Dugas et al. 2015). It is well stablished that calling is energetically expensive for males in anurans (Pough et al. 1992, Wells 2001, Bevier 2016). Calling subjects males to the risk of being easily located by predators and parasites (Tuttle and Ryan 1981, Gerhardt and Huber 2002, Bernal et al. 2006). However, increasing the time (number of nights in this study) that a male is calling is often associated with higher mating success in anurans (Greer and Wells 1980, Jacobson 1985, Wells 2007, Mangold et al. 2015). Therefore, the number of nights a male calls is influenced by intrinsic physiological and biochemical characteristics and extrinsic local environmental factors (Gerhardt and Huber 2002, Bevier 2016). Further studies will be necessary to establish whether males of $N$. grandisonae calling more nights obtain higher mating opportunities but are more prone to predation than males calling fewer nights.

A positive relationship between rainfall and the number of males calling in $N$. grandisonae has been found in multiple anuran lineages (Dendrobatidae: Pröhl and Hödl 1999; Microhylidae: Prado et al. 2005 and Hawley 2006; Hylidae: Muñoz-Guerrero et al. 2007; Bufonidae: Ngo and Ngo 2013; Leptodactylidae: Giaretta and Menin 2004; Centrolenidae: Cabanzo-Olarte et al. 2013, Noronha and Rodrigues 2018). This relationship has been attributed to the dependence of anuran species on humid environmental conditions and water bodies for oviposition and the subsequent 


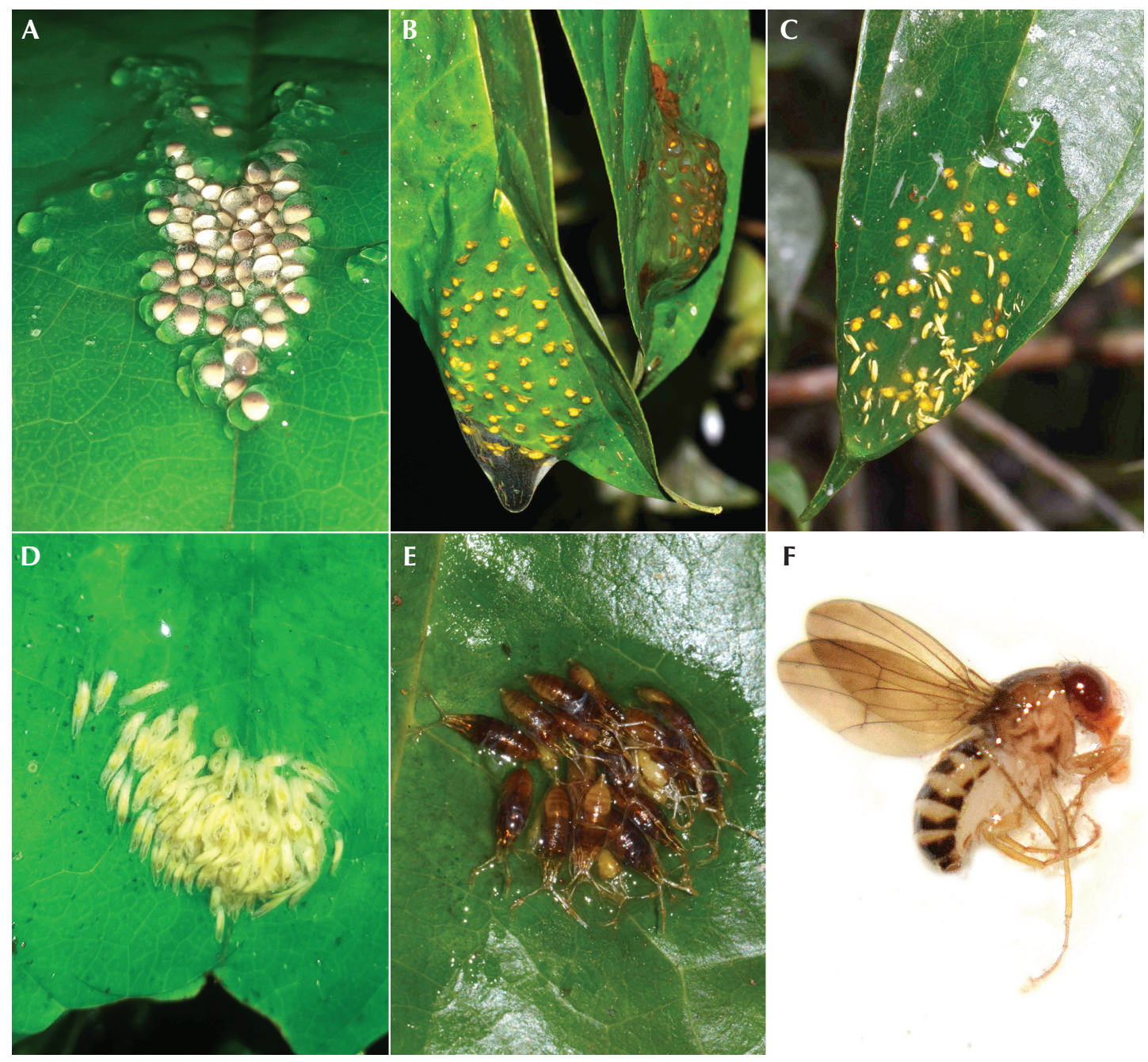

Figure 5. Clutches of the glass frog Nymphargus grandisonae and development sequence of the fly larvae of genus c.f. Cladochaeta: Drosophilidae. Image of a clutch minutes after oviposition (A), and after some days of embryo development (B); note that the clutches swell because the volume of the jelly matrix covering eggs increases. Image of an infested clutch by fly larvae in early stages of development; embryos of $\mathrm{N}$. grandisonae are still observed $(\mathbf{C})$. Clutch when the embryos of $N$. grandisonae are gone and only larvae of the fly remains (D). Clutch in advanced stage of fly larvae infestation (E). External morphology of the fly after emerging from the pupae (F).

development of embryos and tadpoles (Wells 2007). In contrast, we did not find any association between temperature and number of males calling in $N$. grandisonae, despite this factor playing an important role in the reproductive phenology of many anurans (Saenz et al. 2006, Steen et al. 2013, Green 2016). Breeding activity patterns in tropical anurans is mainly related to rainfall (Crump 1974, Aichinger 1987, Duellman 1995, Gibbs and Breisch 2001, Wells 2007, 
Segev et al. 2012) unlike anuran species of temperate zones, in which phenological patterns are influenced mainly by temperature (Reading 1998, Silva-Ximenez and Tozetti 2015, Plenderleith et al. 2017).

We recaptured 19 of 31 males, but no females were recaptured. This result is frequent in studies of reproductive activity of anurans because males remain at breeding sites longer than females (Duellman and Trueb 1994, Wells 2007, Vitt and Caldwell 2014). Moreover, in several species the females skip reproductive seasons without breeding (Halliday and Tejedo 1995). Males of $N$. grandisonae are highly territorial and engage in physical contests (Hutter et al. 2013b), and endurance rivalry is a male-male competition mechanism usually associated with mating success in glass frogs (Greer and Wells 1980, Jacobson 1985, Mangold et al. 2015, Basto-Riasco et al. 2017, Ospina-L et al. 2017). This behavior may be associated with a positive relationship between male body size and the number of nights a male of a $N$. grandisonae was recorded calling (a proxy to endurance rivalry in anurans) and not an artifact of our sampling design (i.e. surveys separated by one or two weeks). Further studies are necessary to corroborate this hypothesis because patterns of timing of breeding in anurans may or may not be associated with male body size (HernándezSalinas et al. 2018, Torres-Cervantes et al. 2019, Pompeu et al. 2020).

The number of egg clutches could be used as an indicator of the level of reproductive activity of females in anurans (Wells 2007, Vitt and Caldwell 2014). In species with oviposition out of water, oviposition may be associated with high rainfall or with microhabitats that remains wet even in summer (e.g. under roots and fallen trunks, cavities in the ground) (Crump 1974, Wells 2007, Vargas-Salinas et al. 2014, OrtizRoss et al. 2020). In the case of $N$. grandisonae, clutches are laid on leaves and thus, during development, embryos are exposed to environmental conditions that make them dependent on the presence of rainfall and temperature for survival and development
(Ospina-Sarria et al. 2011, Delia et al. 2020). Therefore, we did not expect the absence of a relationship between the number of clutches of $N$. grandisonae and the levels of environmental temperature and precipitation we found. Females of $N$. grandisonae might avoid to depositing eggs near the peak of rainfall because heavy storms could promote clutch mortality, as recorded in this study. However, it is probable that the absence of said relationship is a sampling artifact. This possibility is because numerous clutches of $N$. grandisonae could be unrecorded by us, especially those placed at higher locations. In addition, we did not survey every day and night of the reproductive season, which produced a gap between the date of the clutch record and the night that the females performed oviposition. Further detailed data are required to fully understand the relationship between environmental characteristics and the arrival of $N$. grandisonae females at breeding sites. In any case, the observation of clutches throughout the rainy season is the expected pattern in prolonged breeders (Wells 1977, 2007).

Clutches of $N$. grandisonae infested by fly larvae exhibited lower embryonic survival than non-infested clutches. Egg clutches of glass frogs are preyed upon by diverse vertebrates and invertebrates that have been recorded in our study area (Delia et al. 2019, 2020, Ospina-L. et al. 2020), but the infestation by fly larvae was the most common cause of mortality in the study population. Similar observations have been seen in another population of $N$. grandisonae (RojasMorales and Escobar-Lasso 2013) and diverse anurans with oviposition out of water (Wells 2007). For instance, $74 \%$ mortality in egg clutches of Physalaemus cuvieri Fitzinger, 1826 (Leptodactylidae) was attributed to predation by fly larvae of Beckeriella niger (Williston, 1897) (Menin and Giaretta 2003), and $70-100 \%$ of Hyalinobatrachium fleischmanni (Centrolenidae) clutches were infested by larvae of Hirtodrosophila batracida Grimaldi, 1994 (Villa 1977, 1984). Because fly larvae can cause high levels of mortality in terrestrial and arboreal egg clutches, embryos are expected to have evolved 
defensive strategies. Embryos of some anurans have evolved the capacity to evaluate mortality risks and respond accordingly, hatching earlier before reaching an optimal stage of development (Chivers et al. 2001, Warkentin and Caldwell 2009, Cohen et al. 2016). Early hatching is induced in embryos of glass frogs by predation, dehydration, and fungal infection (Delia et al. 2019); thus, it is possible that fly larvae cause similar behavior in $N$. grandisonae. The capture of embryos at stage $17-18$ out of the jelly matrix using the technique of Hayes (1983b) in an infested clutch, do not allow us to test alternate hypotheses. Also, will be necessary to corroborate if the fly larvae feed on embryos of $N$. grandisonae, as reported for other anurans (e.g. Hyalinobatrachium fleischmanni, Agalychnis callidryas (Cope, 1862), and A. annae (Duellman, 1963); Villa 1977, Villa and Townsend 1983, Hughey et al. 2011), or are only using the jelly matrix of the clutch for development.

A thick jelly layer in clutches laid out of water appears to be an adaptation that reduces mortality of embryos by desiccation and predation in glass frogs (Delia et al. 2020), and possibly in other anuran lineages (Duellman and Trueb 1994, Altig and McDiarmid 2007, Wells 2007). However, it is possibly that in some species, for example $N$. grandisonae, such jelly matrix makes egg clutches especially susceptible to be infested by fly larvae. This hypothesis need to be tested, but some suggestive examples supporting it involve clutches infested by dipterans in anurans whose clutches have a thick jelly layer: Espadarana andina (Rivero, 1968) (Cabanzo-Olarte et al. 2013), Agalychnis annae (Villa and Townsend 1983), A. callidryas (Hughey et al. 2011), Hyalinobatrachium fleischmanni (Villa 1977, Hayes 1991), H. valerioi (Vockenhuber et al. 2008), Hyperolius lateralis Laurent, 1940 (Vonesh 2000), and Centrolene peristicta (Lynch and Duellman, 1973) (Salgado and Guayasamín 2018). In addition, two species of glass frogs in the study area (Centrolene savagei, "Centrolene" quindianum Ruiz-Carranza and Lynch, 1995) have clutches without or with only a thin jelly layer, respectively, but during our sampling and previous studies, we did not record fly larvae in their clutches (Rios-Soto et al. 2017, VargasSalinas et al. 2017, Ospina-L et al. 2017, 2020). In spite of said potential cost associated with infestation by fly larvae, comparative analyses and experimental evidence demonstrate for glass frogs that an egg clutch with a thick jelly layer and reduced parental care by females (as in $N$. grandisonae) exhibit a similar overall survivorship to egg clutches with a reduced jelly layer and extended parental care by males (Delia et al. 2020).

Our results show that the glass frog $N$. grandisonae is a prolonged breeder with higher reproductive activity in months with high rainfall. With respect to the causes of mortality in egg clutches, infestation by fly larvae is the factor that reduces the survival of embryos most strongly. More studies are necessary to establish the specificity of the interaction between the fly larvae and the embryos of $N$. grandisonae, and hence, how it would respond to changes in environmental conditions (Marcogliese 2001). Aspects of natural history and the causes of mortality such as those recorded in this study offer baseline data that will provide a better understanding of the ecology, behavior and evolutionary biology of glass frogs, and will aid in the design of conservation and management plans (Clemmons and Buchholz 1997, Paton and Crouch III 2002).

\section{Acknowledgments}

We thank Ana R. Acevedo, Orlando Muñoz, David A. Muñoz, Juan C. Muñoz, Oliva Mora and Ana C. We thank engineer Jorge I. Salazar for granting us permission to access the study area and Alfonso Osorio and Luz Grajales for their logistical support in food and lodging. We thank Julián Ríos, Ana Ospina-L, Natalia Belduque, Cristián Gonzales, Juan D Carvajal and Andrea Zuluaga for their accompaniment in fieldwork. Thanks to Deivys M. Alvarez for 
helping with the taxonomic identity of the fly larvae. Finally, thanks to the director of the Biology Program of the University of Quindío, German Darío Gómez, for his unconditional support. Previous versions of this manuscript were greatly improved by comments by Jaime Bertoluci, Carlos Navas, Kyle Summers, Laurie J Vitt and Janalee P Caldwell, and an anonymous reviewer.

\section{References}

Aichinger, M. 1987. Annual activity patterns of anurans in a seasonal neotropical environment. Oecologia 71: 583-592.

Altig, R. and R. W. McDiarmid. 2007. Morphological diversity and evolution of egg and clutch structure in amphibians. Herpetological Monographs 21: 1-32.

Andrade, D. V., C. R. Bevier, and J. E. Carvalho (eds.). 2016. Amphibian and Reptile Adaptations to the Environment: Interplay between Physiology and Behavior. Boca Raton, London, and New York. CRC Press. 214 pp.

Arcila, P. J., V. H. Ramírez, and R. A. Jaramillo. 2011. Patrones de Distribución de la Lluvia en la Zona Cafetera. Manizales. Centro Nacional de Investigaciones de Café Cenicafé. 11 pp.

Arcila-Pérez, L. F., J. A. Rios-Soto, S. O. Montilla, C. A. Londoño-Guarnizo, C. Gómez, and F. Vargas-Salinas. 2017. Vocalizations and natural history in populations of a glass frog assigned to Nymphargus griffithsi in Central Andes of Colombia. Herpetological Review 48: 275-280.

Arteaga, A. F., L. Bustamante, and J. M. Guayasamin. 2013. The Amphibians and Reptiles of Mindo. Life in the Cloud Forest. Quito. Universidad Tecnológica Indoamérica. Serie de Publicaciones Científicas. 257 pp.

Basto-Riascos, M. C., J. López-Caro, and F. Vargas-Salinas. 2017. Reproductive ecology of the glass frog Espadarana prosoblepon (Anura: Centrolenidae) in an urban forest of the Central Andes of Colombia. Journal of Natural History 51: 2535-2550.

Bernal, M. H. and J. D. Lynch. 2008. Review and analysis of altitudinal distribution of the Andean anurans in Colombia. Zootaxa 1826: 1-25.

Bernal, X. E., A. S. Rand, and M. J. Ryan. 2006. Acoustic preferences and localization performance of bloodsucking flies (Corethrella Coquillett) to túngara frog calls. Behavioral Ecology 17: 709-715.
Bevier, C. R. 2016. Physiological and biochemical correlates of calling behavior in anurans with different calling strategies. Pp. 63-79 in D. V. Andrade, C. R. Bevier, and J. E. Carvalho (eds.), Amphibian and Reptile Adaptations to the Environment: Interplay Between Physiology and Behavior. Boca Raton. CRC Press Taylor \& Francis Group.

Cabanzo-Olarte, L. C., M. P. Ramírez-Pinilla, and V. H. Serrano-Cardozo. 2013. Oviposition, site preference, and evaluation of male clutch attendance in Espadarana andina (Anura: Centrolenidae). Journal of Herpetology 47: 314-320.

Castaño, H. J. and J. A. Carranza-Quiceno (eds.). 2015. Campoalegre Biodiversidad en un Paisaje Cultural Andino de Risaralda. Chinchiná. CARDER, Universidad Santa Rosa de Cabal-UNISARC. 183 pp.

Chivers, D. P., J. M. Kiesecker, A. Marco, J. D. Vito, M. T. Anderson, and A. R. Blaustein. 2001. Predator-induced life history changes in amphibians: egg predation induces hatching. Oikos 92: 135-142.

Chuine, I. and J. Régnière. 2017. Process-based models of phenology for plants and animals. Annual Review of Ecology, Evolution, and Systematics 48: 159-182.

Cisneros-Heredia, D. F. and R. W. McDiarmid. 2007. Revision of the characters of Centrolenidae (Amphibia: Anura: Athesphatanura), with comments on its taxonomy and the description of new taxa of glass frogs. Zootaxa 1572: 1-82.

Clemmons, J. R. and R. Buchholz (eds.). 1997. Behavioral Approaches to Conservation in the Wild. Cambridge. Cambridge University Press. 382 pp.

Cohen, K. L., M. A. Seid, and K. M. Warkentin. 2016. How embryos escape from danger: the mechanism of rapid, plastic hatching in red-eyed treefrogs. Journal of Experimental Biology 219: 1875-1883.

Crenshaw, J. W. 1966. Natural selection, the costs of reproduction, and a refinement of lack's principle. American Naturalist 100: 687-690.

Crump, M. L. 1974. Reproductive strategies in a tropical anuran community. Miscellaneous Publications of the Museum of Natural History University of Kansas 61: $1-68$.

Crump, M. L. and N. J. Scott Jr. 1994. Standard techniques for inventory and monitoring. Pp. 78-83 in W. R. Heyer, M. A. Donnelly, R. W. McDiarmid, Lee-Ann. C. Hayek, and M. S. Foster (eds.), Measuring and Monitoring Biological Diversity: Standard Methods for Amphibians. Washington. Smithsonian Institution Press. 
Delia, J., D. F. Cisneros-Heredia, J. Whitney, and R. Murrieta-Galindo. 2010. Observations on the reproductive behavior of a Neotropical glassfrog, Hyalinobatrachium fleischmanni (Anura: Centrolenidae). South American Journal of Herpetology 5: 1-12.

Delia, J. R. J., A. Ramírez-Bautista, and K. Summers. 2013. Parents adjust care in response to weather conditions and egg dehydration in a Neotropical glass frog. Behavioral Ecology and Sociobiology 67: 557-569.

Delia, J. R. J., A. Ramírez-Bautista, and K. Summers. 2014. Glass frog embryos hatch early after parental desertion. Proceedings of the Royal Society B 281: 2013-3237.

Delia, J., L. Bravo-Valencia, and R. W. McDiarmid. 2017. Notes on paternal behavior in Hyalinobatrachium glass frogs (Anura: Centrolenidae). Phyllomedusa 16: 101107.

Delia, J., J. M. Rivera-Ordonez, M. J. Salazar-Nicholls, and K. M. Warkentin. 2019. Hatching plasticity and the adaptive benefits of extended embryonic development in glass frogs. Evolutionary Ecology 33: 37-53.

Delia, J., Bravo-Valencia, L, and K. M. Warkentin. 2020. The evolution of extended parental care in glassfrogs: do egg-clutch phenotypes mediate coevolution between the sexes? Ecological Monographs 90: e01411.

Díaz-Ricaurte, J. C., E. C. Guevara-Molina, and F. Serrano. 2019. Oviposition site preference and reproductive ecology of Teratohyla midas (Anura: Centrolenidae) in the Colombian Amazon. Journal of Natural History 53: $1811-1822$.

Dodd Jr., C. K., J. Loman, D. Cogălniceanu, and M. Puky. 2012. Monitoring amphibian populations. Pp. $3577-$ 3635 in H. Heatwole and J. W. Wilkinson (eds.), Amphibian Biology. Sydney. Surrey Beatty \& Sons.

Donnelly, M. A., C. Guyer, J. E. Juterbock, and R. A. Alford. 1994. Techniques for marking amphibians. Pp. 277-284 in W. R. Heyer, M. A. Donnelly, R. W. McDiarmid, Lee-Ann. C. Hayek, and M. S. Foster (eds.), Measuring and Monitoring Biological Diversity: Standard Methods for Amphibians. Washington. Smithsonian Institution Press.

Duellman, W. E. 1980. The identity of Centrolenella grandisonae Cochran and Goin (Anura: Centrolenidae). Transactions of the Kansas Academy of Science 83: 2632.

Duellman, W. E. 1995. Temporal fluctuations in abundances of Anuran Amphibians in a seasonal Amazonian rainforest. Journal of Herpetology 29: 13-21.

Duellman, W. E. and L. Trueb. 1994. Biology of Amphibians. London. John Hopkins University Press. 613 pp.
Dugas, M. B., C. N. Wamelink, and C. L. Richards-Zawacki. 2015. Both sexes pay a cost of reproduction in a frog with biparental care. Biological Journal of the Linnean Society 115: 211-218.

Dyson, M. L., S. P. Henzi, T. R. Halliday, and L. Barrett. 1998. Success breeds success in mating male reed frogs (Hyperolius marmoratus). Proceedings of the Royal Society B 265: 1417-1421.

Ferner, J. W. 2010. Measuring and marking postmetamorphic amphibians. Pp. 123-141 in C. K. Dodd Jr. (eds.), Amphibian Ecology and Conservation. A Handbook of Techniques. New York. Oxford University Press.

Franco, A. M. and G. A. Bravo. 2005. Áreas importantes para la conservación de las Aves en Colombia. Pp. 117281 in K. Boyla and A. Estrada (eds.), Áreas Importantes para la Conservación de las Aves de los Andes Tropicales: Sitios Prioritarios para la Conservación de la Biodiversidad. Quito. BirdLife International \& Conservation International.

Friedl, T. W. P. and G. M. Klump. 2005. Sexual selection in the lek-breeding European treefrog: body size, chorus attendance, random mating and good genes. Animal Behaviour 70: 1141-1154.

Frost, D. R. 2020. Amphibian species of the world: An Online Reference. Version 6.0 (January 2014) Electronic Database accessible at http://research.amnh.org/ herpetology/amphibia/American Museum of Natural History, New York, USA. Captured on 21 October 2020.

Gerhardt, H. C. and F. Huber. 2002. Acoustic Communication in Insects and Anurans: Common Problems and Diverse Solutions. Chicago and London. University of Chicago Press. 531 pp.

Giaretta, A. A. and M. Menin. 2004. Reproduction, phenology and mortality sources of a species of Physalaemus (Anura: Leptodactylidae). Journal of Natural History 38: 1711-1722.

Gibbs, J. P. and A. R. Breisch. 2001. Climate warming and calling phenology of frogs near Ithaca. Conservation Biology 15: 1175-1178.

Gosner, K. L. 1960. A simplified table for staging anuran embryos and larvae with notes on identification. Herpetologica 16: 183-190.

Green, D. M. 2016. Amphibian breeding phenology trends under climate change: predicting the past to forecast the future. Global Change Biology 23: 646-656.

Greer, B. J. and K. D. Wells. 1980. Territorial and reproductive behavior of the tropical American frog Centrolenella fleischmanni. Herpetologica 36: 318-326. 
Grimaldi, D. 1990. A phylogenetic, revised classification of genera in the Drosophilidae (Diptera). Bulletin of the American Museum of Natural History 197: 1-139.

Guevara-Molina, E. C. and F. Vargas-Salinas. 2014. Nymphargus grandisonae (red-spotted glass frog): reproductive behaviour. Herpetological Bulletin 128: 29-30.

Halliday, T. and M. Tejedo. 1995. Intrasexual selection and alternative mating behaviour. Pp. 419-468 in $\mathrm{H}$. Heatwole and B. K. Sullivan (eds.), Amphibian Biology. Volume 2. Social Behaviour. Sydney. Surrey Beatty \& Sons.

Hawley, T. J. 2006. Embryonic development and mortality in Hyalinobatrachium pulveratum (Anura: Centrolenidae) of southwestern Costa Rica. Journal of Tropical Ecology 22: 731-734.

Hayes, M. P. 1983a. Predation on the adults and prehatching stages of glass frogs (Centrolenidae). Biotropica 15: $74-76$.

Hayes, M. P. 1983b. A technique for partitioning hatching and mortality estimates in leaf-breeding frogs. Herpetological Review 14: 115-116.

Hayes, M. P. 1991. A study of clutch attendance in the Neotropical frog Centrolenella fleischmanni (Anura: Centrolenidae). Ph.D. Thesis. University of Miami, Coral Gables, Miami, USA.

Hernández-Salinas, U., A. Ramírez-Bautista, B. P. Stephenson, R. Cruz-Elizalde, C. Berriozabal-Islas, and C. J. Balderas-Valdivia. 2018. Amphibian life history in a temperate environment of the Mexican Plateau: dimorphism, phenology and trophic ecology of a hylid frog, Hyla eximia (= Dryophytes eximius). PeerJ 6: e5897.

Hughey, M.-C., A. Nicolás, J. R. Vonesh, and K. M. Warkentin. 2011. Wasp predation drives the assembly of fungal and fly communities on frog egg masses. Oecologia 168: 1057-1068.

Hutter, C. R., J. M. Guayasamin, and J. J. Wiens. 2013a. Explaining Andean megadiversity: the evolutionary and ecological causes of glass frog elevational richness patterns. Ecology Letters 16: 1135-1144.

Hutter, C. R., S. Esobar-Lasso, J. A. Rojas-Morales, P. D. A. Gutiérrez-Cárdenas, H. Imba, and J. M. Guayasamin. 2013b. The territoriality, vocalizations and aggressive interactions of the red-spotted glassfrog, Nymphargus grandisonae, Cochran and Goin, 1970 (Anura: Centrolenidae). Journal of Natural History 47: 3011-3032.

IBM. 2012. IBM SPSS statistics for Windows, Version 21.0. Armonk (NY): IBM Corp. URL: https://www.ibm. com/support/home/
Jacobson, S. K. 1985. Reproductive behavior and male mating success in two species of glass frogs (Centrolenidae). Herpetologica 41: 396-404.

Juncá, F. A. 1996. Parental care and egg mortality in Colostethus stepheni. Journal of Herpetology 30: 292294.

Lillywhite, H. B. 2014. How Snakes Work: Structure, Function, and Behavior of the World's Snakes. New York. Oxford University. 256 pp.

Lips, K. R., P. A. Burrowes, J. R. Mendelson III, and G. Parra-Olea. 2005. Amphibian declines in Latin America: widespread population declines, extinctions, and impacts. Biotropica 37: 163-165.

Llusia, D., R. Márquez, J. F. Beltrán, M. Benítez, and J. P. Amaral. 2013. Calling behaviour under climate change: geographic and seasonal variation of calling temperatures in ectotherms. Global Change Biology 19: $2655-2674$.

Losos, J. B. 2009. Lizards in an Evolutionary Tree: Ecology and Adaptive Radiation of Anoles. Berkeley and London. University of California Press. 528 pp.

Mangold, A., K. Trenkwalder, M. Ringler, W. Hödl, and E. Ringler. 2015. Low reproductive skew despite high male-biased operational sex ratio in a glass frog with paternal care. BMC Evolutionary Biology 15: 1-13.

Marcogliese, D. J. 2001. Implications of climate change for parasitism of animals in the aquatic environment. Canadian Journal of Zoology 79: 1331-1352.

McCauley, S.-J., S. S. Bouchard, B. J. Farina, K. Isvaran, S. Quader, D. W. Wood, and C. M. St. Mary. 2000. Energetic dynamics and anuran breeding phenology: insights from a dynamic game. Behavioral Ecology 11: 429-436.

McDiarmid, R. W. 1978. Evolution of parental care in frogs. The development of behavior: Comparative and evolutionary aspects. Pp. 127-147 in G. M. Burghardt and M. Bekoff (eds.), The Development of Behavior. New York. Garland Press.

Menin, M. and A. A. Giaretta. 2003. Predation on foam nests of leptodactyline frogs (Anura: Leptodactylidae) by larvae of Beckeriella niger (Diptera: Ephydridae). Journal of Zoology 261: 239-243.

Mistlberger, R. A. and B. Rusak, 2005, Biological rhythms and behavior. Pp. 71-96 in J. J. Bolhuis and L. A. Giraldeau (eds.), The Behavior of Animals. $1^{\text {st }}$ Edition. West Sussex. Wiley-Blackwell Publishing.

Muñoz-Guerrero, J., V. H. Serrano, and M. P. RamírezPinilla. 2007. Microhabitat use, diet and time of activity 
of four sympatric Neotropical hylid frogs (Anura: Hylidae). Caldasia 29: 413-425.

Navas, C. A. 2002. Herpetological diversity along Andean elevational gradients: links with physiological ecology and evolutionary physiology. Comparative Biochemistry and Physiology 133: 469-485.

Navas, C. A. 2006. Patterns of distribution of anurans in high Andean tropical elevations: insights from integrating biogeography and evolutionary physiology. Integrative and Comparative Biology 46: 82-91.

Navas, C.-A., J. M. Carvajalino-Fernández, L. P. SaboyáAcosta, L. A. Rueda-Solano, and M. A. CarvajalinoFernández. 2013. The body temperature of active amphibians along a tropical elevation gradient: patterns of mean and variance and inference from environmental data. Functional Ecology 27: 1145-1154.

Neckel-Oliveira, S. and M. Wachlevski. 2004. Predation on the arboreal eggs of three species of Phyllomedusa in Central Amazonia. Journal of Herpetology 38: 244 248.

Ngo, B. V. and C. D. Ngo. 2013. Reproductive activity and advertisement calls of the Asian common toad Duttaphrynus melanostictus (Amphibia, Anura, Bufonidae) from Bach Ma National Park, Vietnam. Zoological Studies 52: 1-13.

Noronha, J. C. and D. J. Rodrigues. 2018. Reproductive behaviour of the glass frog Hyalinobatrachium cappellei (Anura:Centrolenidae) in the Southern Amazon. Journal of Natural History 52: 207-224.

Ortiz-Ross, X., M. E. Thompson, E. Salicetti-Nelson, O. Vargas-Ramírez, and M. A. Donnelly. 2020. Oviposition site selection in three glass frog species. Copeia 108: 333-340.

Ospina-L., A. M., J. A. Rios-Soto, and F. Vargas-Salinas. 2017. Size, endurance, or parental care performance? male-male competition, female choice, and non-random mating pattern in the glass frog Centrolene savagei. Copeia 105: 575-583.

Ospina-L., A. M., P. Navarro-Salcedo, J. A. Rios-Soto, S. Duarte-Marín, and F. Vargas-Salinas. 2020. Temporal patterns, benefits, and defensive behaviors associated with male parental care in the glass frog Centrolene savagei. Ethology Ecology \& Evolution 32: 162-174.

Ospina-Sarria, J. J., W. Bolívar-G, J. Mendez-Narvaez, and C. Burbano-Yandi. 2011. The tadpole of Nymphargus grandisonae (Anura, Centrolenidae) from Valle del Cauca, Colombia. South American Journal of Herpetology 6: 79-86.
Paton, P. W. and W. B. Crouch III. 2002. Using the phenology of pond-breeding amphibians to develop conservation strategies. Conservation Biology 16: 194204.

Plenderleith, T. L., D. Stratford, G. W. Lollback, D. G. Chapple, R. D. Reina, and J. M. Hero. 2017. Calling phenology of a diverse amphibian assemblage in response to meteorological conditions. International Journal of Biotechnology 62: 873-882.

Pompeu, C. C. L., F. P. de Sá, and C. F. B. Haddad. 2020. Seasonal reproductive dynamics of a lek-breeding Neotropical treefrog is not organized by male size (Anura, Hylidae). South American Journal of Herpetology 18: 33-41.

Pough, F. H., W. E. Magnusson, M. J. Ryan, K. D. Wells, and T. L. Taigen. 1992. Behavioral energetics. Pp. 395436 in M. E. Feder and W. W. Burggren (eds.), Environmental Physiology of the Amphibians. Chicago and London. University of Chicago Press.

Prado, C., M. Uetanabaro, and C. F. B. Haddad. 2005. Breeding activity patterns, reproductive modes, and habitat use by anurans (Amphibia) in a seasonal environment in the Pantanal, Brazil. Amphibia-Reptilia 26: 211-221.

Pröhl, H. 2003. Variation in male calling behaviour and relation to male mating success in the strawberry poison frog (Dendrobates pumilio). Ethology 109: 273-290.

Pröhl, H. and W. Hödl. 1999. Parental investment, potential reproductive rates, and mating system in the strawberry dart-poison frog, Dendrobates pumilio. Behavioral Ecology and Sociobiology 46: 215-220.

Reading, C. J. 1998. The effect of winter temperatures on the timing of breeding activity in the common toad Bufo bufo. Oecologia 117: 469-475.

Renjifo, L. M. 2001. Effect of natural and anthropogenic landscape matrices on the abundance of subandean bird species. Ecological Applications 11: 14-31.

Rios-Soto, J. A., A. M. Ospina-L, and F. Vargas-Salinas. 2017. The advertisement call and notes on the reproductive ecology of the glass frog "Centrolene" quindianum (Anura: Centrolenidae). South American Journal of Herpetology 12: 117-127.

Rojas-Morales, J. A. and S. Escobar-Lasso. 2013. Notes on the natural history of three glass frogs species (Anura: Centrolenidae) from the Andean Central cordillera of Colombia. Boletín Científico Centro de Museos de Historia Natural 17: 127-140.

Saenz, D., L. A. Fitzgerald, K. A. Baum, and R. N. Conner. 2006. Abiotic correlates of anuran calling phenology: the 
importance of rain, temperature, and season. Herpetological Monographs 20: 64-82.

Salazar-Nicholls, M. J. and M. E. del Pino. 2015. Early development of the glass frogs Hyalinobatrachium fleischmanni and Espadarana callistomma (Anura:Centrolenidae) from cleavage to tadpole hatching. Amphibian \& Reptile Conservation 8: 89-106.

Salgado, A. L. and J. M. Guayasamín. 2018. Parental care and reproductive behavior of the minute dappled glass frog (Centrolenidae: Centrolene peristictum). South American Journal of Herpetology 13: 211-219.

Salica, M. J., J. R. Vonesh, and K. M. Warkentin. 2017. Egg clutch dehydration induces early hatching in red-eyed treefrogs, Agalychnis callidryas. PeerJ 5: e3549.

Samplonius, J. M. and C. Both. 2017. Competitor phenology as a social cue in breeding site selection. Journal of Animal Ecology 86: 615-623.

Schaffer, W. M. 1974. Selection for optimal life histories: the effects of age structure. Ecology 55: 291-303.

Segev, O., F. Andreone, R. Pala, G. Tessa, and M. Vences. 2012. Reproductive phenology of the tomato frog, Dyscophus antongili, in an urban pond of Madagascar's east coast. Acta Herpetologica 7: 331-340.

Silva-Ximenez, S. and A. M. Tozetti. 2015. Seasonality in anuran activity and calling season in a Brazilian subtemperate wetland. Zoological Studies 54: 1-9.

Sockman, K. W., P. J. Sharp, and H. Schwabl. 2006. Orchestration of avian reproductive effort: an integration of the ultimate and proximate bases for flexibility in clutch size, incubation behaviour, and yolk androgen deposition. Biological Reviews 81: 629-666.

Steen, D. A., C. W. McClure, and S. P. Graham. 2013. Relative influence of weather and season on anuran calling activity. Canadian Journal of Zoology 91: 462 467.

Strier, K. B. 2017. Primate Behavioral Ecology. London and New York. Routledge Taylor \& Fracis group. 602 pp.

Therneau, T. M. and P. M. Grambsch. 2000. Modeling Survival Data: Extending the Cox Model. New York. Springer-Verlag. 350 pp.

Toledo, L. F. 2007. Predação e defesa em anuros: revisão, descrição e evolução. Ph. D. Thesis. Universidade Estadual Paulista "Julio de Mesquita Filho", Rio Claro, Brasil.

Torres-Cervantes, R., A. Ramírez-Bautista, C. BerriozabalIslas, R. Cruz-Elizalde, and U. Hernández-Salinas. 2019. Morphology and reproductive patterns of an assemblage of anurans from the Chihuahuan desert region, Mexico. Journal of Arid Environments 165: 28-33.
Touchon, J. C. and K. M. Warkentin. 2010. Short- and longterm effects of the abiotic egg environment on viability, development and vulnerability to predators of a Neotropical anuran. Functional Ecology 24: 566-575.

Tuttle, M. D. and M. J. Ryan. 1981. Bat predation and the evolution of frog vocalizations in the Neotropics. Science 214: 677-678.

Vanegas-Guerrero, J., V. A. Ramírez-Castaño, and E.C. Guevara-Molina. 2014. Nymphargus grandisonae (Cochran y Goin 1970). Catálogo de Anfibios y Reptiles de Colombia 2: 51-55.

van Shaik, C. P., J. W. Terborgh, and S. J. Wright. 1993. The phenology of tropical forest: adaptive significance and consequences for primary consumers. Annual Review of Ecology, Evolution, and Systematics 24: 353-377.

Vargas-Salinas, F., A. Dorado-Correa, and A. Amézquita. 2014. Microclimate and stream noise predict geographic divergence in the auditory signal of a threatened poison frog. Biotropica 46: 748-755.

Vargas-Salinas, F., A. M. Ospina-L., J. A. Rios-Soto, and M. Rivera-Correa. 2017. Centrolene savagei. Catalogue of American Amphibians and Reptiles 912: 1-11.

Vargas-Salinas, F., J. Muñoz-Ávila, M. E. Morales (eds.). 2019. Biología de Anfibios y Reptiles en el Bosque Seco Tropical del Norte de Colombia. Tunja. Editorial UPTC. $484 \mathrm{pp}$.

Vasconcelos, T. S., F. R. Silva, T. G. Santos, V. H. Prado, and D. B. Provete. 2019. Biogeographic Patterns of South American Anurans. Cham. Springer Nature Switzerland. 159 pp.

Verhulst, S. and J. M. Tinbergen. 1991. Experimental evidence for a causal relationship between timing and success of reproduction in the great tit Parus m. major. Journal of Animal Ecology 60: 269-282.

Villa, J. 1977. A symbiotic relationship between frog (Amphibia, Anura, Centrolenidae) and fly larvae (Drosophilidae). Journal of Herpetology 11: 317-322.

Villa J. 1984. Biology of a neotropical glass frog, Centrolenella fleischmanni (Boettger), with special reference to its frogfly associates. Milwaukee Public Museum Contributions in Biology and Geology 55: $1-60$.

Villa, J. and D. S. Townsend. 1983. Viable frog eggs eaten by phorid fly larvae. Journal of Herpetology 17: 278281.

Vitt, J. L. and J. P. Caldwell. 2014. Herpetology. An Introductory Biology of Amphibians and Reptiles. Oklahoma. Academic Press \& Elsevier. 731 pp. 
Vockenhuber, E. A., W. Hödl, and U. Karpfen. 2008. Reproductive behaviour of the glass frog Hyalinobatrachium valerioi (Anura: Centrolenidae) at the tropical stream Quebrada Negra (La Gamba, Costa Rica). Stapfia 88: 335-348.

Vonesh, J. R. 2000. Dipteran predation on the arboreal eggs of four Hyperolius frog species in Western Uganda. Copeia 2000: 560-566.

Walls, S. C., W. J. Barichivich, and M. E. Brown. 2013. Drought, deluge and declines: the impact of precipitation extremes on amphibians in a changing climate. Biology 2: $399-418$.

Warkentin, K. M. 1995. Adaptive plasticity in hatching age: a response to predation risk trade-offs. Proceedings of the National Academy of Sciences 92: 3507-3510.

Warkentin, K. M. and M. S. Caldwell. 2009. Assessing risk: embryos, information, and escape hatching. Pp. 177-200 in R. Dukas and J. M. Ratcliffe (eds.), Cognitive Ecology II. Chicago and London. The University of Chicago Press.

Wells, K. D. 1977. The social behavior of anuran amphibians. Animal Behaviour 25: 666-693.
Wells, K. D. 2001. The energetics of calling in frogs. Pp. 45-60 in M. J. Ryan (ed.), Anuran Communication. Washington. Smithsonian Institution Press.

Wells, K. D. 2007. The Ecology and Behavior of Amphibians. Chicago and London. University of Chicago Press. 1400 pp.

Winkler, D. W. 2016. Breeding biology of birds. Pp. 407450 in I. J. Lovette, and J. W. Fitzpatrick (eds.), Handbook of Bird Biology. $3^{\text {rd }}$ Edition. West Sussex. Wiley-Blackwell Publishing, John Wiley \& Sons, Cornell University.

Yánez-Muñoz, M. and S. Ramírez. 2008. Análisis de Diversidad Herpetofaunística en el Sector Cordillera de Atacazo-Saloya (Distrito Metropolitano de Quito). Quito. Museo Ecuatoriano de Ciencias Naturales, División de Herpetología. 13 pp.

Zina, J. and C. F. B. Haddad. 2005. Reproductive activity and vocalizations of Leptodactylus labyrinthicus (Anura: Leptodactylidae) in Southeastern Brazil. Biota Neotropica 5: 1-11. 